\title{
CANISTER DISPOSITION PLAN FOR THE DWPF STARTUP TEST PROGRAM (U)
}

by

J. R. Harbour

Westinghouse Savannah River Company

Savannah River Site

Aiken, South Carolina 29808

C. H. Payne

(WSRC)

This paper was prepared in connection with work done under the above contract number with the U. S.

Department of Energy. By acceptance of this paper, the publisher and/or recipient acknowledges the U. S.

Government's right to retain a nonexclusive, r כyalty-free license in and to any copyright covering this paper, along with the right to reproduce and to authorize others to reproduce all or part of the copyrighted paper. 


\section{DISCLAIMER}

This report was prepared as an account of work sponsored by an agency of the United States.Government. Neither the United States Government nor any agency thereof, nor any of their employees, makes any warranty, express or implied, or assumes any legal liability or responsibility for the accuracy, completeness, or usefulness of any information, apparatus, product, or process disclosed, or represents that its use would not infringe privately owned rights. Reference herein to any specific commercial product, process, or service by trade name, trademark, manufacturer, or otherwise does not necessarily constitute or imply its endorsement, recommendation, or favoring by the United States Government or any agency thereof. The views and opinions of authors expressed herein do not necessarily state or reflect those of the United States Government or any agency thereof.

This report has been reproduced directly from the best available copy.

Available to DOE and DOE contractors from the Office of Scientific and Technical Information, P.O. Box 62, Oak Ridge, TN 37831; prices available from (615) 576-8401, FTS 626-8401.

Available to the public from the National Technical Information Service, U.S. Department of Commerce, 5285 Port Royal Rd., Springfield, VA 22161. 


\section{CANTSTYRR DISPOSITION PTIAN FOR TATS DKPF STARTOP THFST PROGRAY}

\subsection{INTRODOCTION}

This report details the disposition of canisters and the canistered waste forms produced during the DWPF startup Test Program. The six melter campaigns (DWPF startup mests FA-13, WP-14, WP-15, WP-16, WP-17, and FA-18) will produce 126 canistered waste forms. In addition, up to 20 additional canistered waste forms may be produced from glass poured during the transition between campaigns. In particular, this canister disposition plan (1) assigns (by alpha-numeric code) a specific canister to each location in the six campaign sequences, (2) describes the method of access for glass sampling on each canistered waste form, (3) describes the nature of the specific tests which will be carried out, (4) details which tests will be carried out on each canistered waste form, (5) provides the sequence of these tests for each canistered waste form, and (6) assigns a storage location for each canistered waste form. The tests are designed to provide evidence, as detailed in the Waste Form Compliance Plan (WCP ${ }^{1}$ ), that the DWPF product will comply with the Waste Acceptance Product Specifications $\left(\right.$ WAPS $\left.^{2}\right)$. The WAPS must be met before the canistered waste form is accepted by DOE for ultimate disposal at the Federal Repository. The results of these tests will be included in the waste Form Qualification Report (WQR).

The testing associated with each designated canistered waste form is presented in the Attachments from both a sequential and a canister code order in Attachments \#1 and \#2. Attachment \#3 is a summary of the testing, and Attachment \#4 provides the sequence of operations and tests for canistered waste forms undergoing tests.

It is the intent of this plan to take advantage of data acquistion opportunities as they arise. An example here would be a failure of an ICC seal to meet the leakrate specification. Normally, the procedure calls for

replacement by an ICC repair plug. However, we will have the option to decide whether to let the canister continue through the process with the failed seal and then measure 
the dew point within this canistered waste form. Some other actions required by this plan will also go against normal DWPF operating procedures. Hence, Startup Procedures must be written in such a way that data can be acquired outside the normal operating conditions.

\section{2 . O OBJECTIVES}

The objectives of the canister disposition plan are to (1) associate a unique canister from one of the five canister vendors with each of the 126 canistered waste forms produced during the six melter campaigns; (2) identify the method of access for glass sampling for each canistered waste form produced; (3) identify and list the sequence of tests to be performed for each canistered waste form in support of DWPF product acceptance; (4) ensure that several canistered waste forms are available for unanticipated, future needs; and (5) ensure that the remains of the cut-and-tested canistered waste forms are safely archived for at least five years.

\subsection{ACTIVITY AND TEST DESCRIPTIONS}

This plan consists of a series of activities and tests designed to demonstrate compliance with the WAPS. The activities and tests (with ref renze numbers in parentheses) are given below The specific tests identified in this plan are part of the DWPF Startup Test Program. The details of the specific tests will be found in the individual Test Plans and their corresponding Test Procedures.

\subsection{Canister Assignment}

Canisters from five different vendors will be used during the DWPF Startup Test Program. Each of the 126 designated canistered waste forms will have a unique canister assigned to it. A number of the canisters had problems associated with vendor documentation and were therefore assigned to the first campaign, FA-13, which is a facilities acceptance rather than waste Qualification campaign. Two deep-drawn canisters are assigned a position in the FA-13 campaign and two seamless canisters produced by spin forming will be filled in WP-17. Two canisters from Westinghouse, 
S00121 and S00122, although out-of-specification in terms of concentricity of the nozzle with the canister, were accepted "as is". They will be filled in FA-13 to see what effect, if any, the out-ofspecification concentricities have on canister handling and closure. Other canisters, with Supplier Deviation disposition Requests, SDDR's, due to documentation and fabrication deficiencies, have been designated to accept the excess glass between campaigns as necessary, and to be placed in the drain turntable to collect glass in the event that an emergency drain is required.

\subsection{Canister Sectioning or wall Removal for Access for Glass Sampling}

The objective here is to provide access to the waste glass within the canister for eventual glass sampling. This will be accomplished through sectioning by sawing or by removal of the canister wall ${ }^{3}$. This sectioning or wall removal will be carried out on most of the canisters in campaigns 2 through 5 (WP-14 through WP17) and on six canistered waste forms from campaign 1 $(\mathrm{EA}-13)$.

\subsection{Glass Sampling from the Canistered Waste Form}

Glass sampling will occur near the plane of sectioning or along the region where a section of the canister wall was removed. This samfling will be done according to the procedure, Glass Sampling of DWPF Canisters, GT-OP 3-059, Rev. 0, January, 1993 by Mary Andrews ${ }^{4}$. Subsequent characterization of the glass samples will be carried out as described in the Glass Sampling Program ${ }^{3}$ and a task plan 5 .

\section{4 Canister Archival}

It is important that the DWPF archive prototypic, glass-filled canistered waste forms as a resource to resolve future, unanticipated concerns. Some of these canistered waste forms will be archived in the Canister Archival Facility at TNX for this purpose. Those canistered waste forms which have been cut-and- 
tested will also be archived in the archival facility at TNX. All canistered waste forms produced during the radioactive cesium spike campaign (FA-18) will be stored in the GWSB.

It is also important to have non-radioactive, glassfilled canisters stored within the GWSB as indicators of environmental effects (such as canister corrosion). Five canistered waste forms from two different vendors will be stored in the GWSB for this purpose. Their locations are indicated in Attachments 1 and 2 .

\subsection{Canister Free Volume Determination (DWPF-WP- 21)}

The free volume will be determined for six of the canistered waste forms ${ }^{6}$. This free volume determination will be carried out on the same canisters which are tested for free liquids and other foreign materials, and for internal pressure. The free volume measurements will be done subsequent to these other tests. Each canistered waste form which is transferred to TNX will be weighed upon receipt as part of the overall strategy for free volume determination.

\subsection{Inner Canister Closure Performance, Repair and Leak Testing (DWPF-FA-12)}

During the Startup Test Program, seven of the canistered waste forms will be leaktested both prior to and after decontamination to ensure that the leaktightness of the temporary seal has not been compromised by the decontamination process or subsequent handling. One of these canistered waste forms will have an ICC repair plug inserted, even if the original ICC seal is within specification. Hence, the leaktightness of the ICC repair plug seal will also be tested both prior to and after decontamination. This canister will then be final welded. One canister will have the tapered plug and sleeve pressed down into the canister after the retesting of the leakrate. This canister, along with the other five canisters, will not undergo final welding. The two spun canisters will require ICC 
repair plugs since they will be received without sleeves.

Several of the canistered waste forms will have their ICC seals tested three times both before and after decontamination to determine reproducibility of the DWPF leakrate measurement.

Once at $\mathrm{TNX}$, the six canistered waste forms without final welds will have their nozzles removed and sent to EES for measurement of the leakrates. These measurements will determine the accuracy of the measurements carried out during operation at DWPF, and provide a leakrate of the ICC seal after being pressed down into the nozzle.

\subsection{Canister Free Iiquid, Pressure and Gas Contents Determination (DWR-WP-22)}

All canistered waste forms produced in the DWPF will be tested for leaktightness of the inner canister closure seal prior to surface decontamination. The ICC seal for each canister must have a helium leak rate less than $2 \times 10^{-4} \mathrm{~atm}-\mathrm{cc} / \mathrm{sec}$ to ensure leaktightness to liquid water. By measuring the relative humidities within 6 canistered waste forms, the capability of the ICC seal to preclude water inleakage will be demonstrated. It is also the intent of this plan to measure the dew point and relative humidity in at least one canistered waste form where the helium leak rate is greater than $2 \times 10^{-4}$ atm$\mathrm{cc} / \mathrm{sec}$ (if such a seal is made). This data will provide us with a measure of safety in using $2 \times 10^{-4}$ atm-cc/sec as the leakrate for exclusion of water.

A systern has been designed to characterize the gas within the free volume of canistered waste form.s ${ }^{7}$. Specially-designed canisters will be fabricated by insertion of a thin-walled tap into the wall of existing canisters and above the projected glass line. ${ }^{8}$ This tap will be pierced, subsequent to glass filling and final closure, without contamination from external air. These experiments will be carried out at TNX by TNX Operations under the direction of GTG. 
The internal gas pressure will be measured, the dew point determined with a hygrometer, and the gas composition determined with a mass spectrometer. The absence of free liquids will be confirmed indirectly by the absence of the corresponding vapors in the gas phase. Similar measurements can be performed if necessary on canisters without $\operatorname{taps}^{7}$.

\subsection{Canister Temperature Profile Determination (DWPF-WP-23)}

Prior to filling, thermocouples will be installed in three canisters in a manner similar to that used in earlier experiments at $\mathrm{TNX}^{9}$. In the first case, the temperature profile within a canister filled on the drain turntable during the low viscosity run (WE-15) will be monitored. This reflects a situation in which problems are encountered with the melter and draining is required to remove the molten waste glass. The use of the drain turntable will also be required at the end of the melter's lifetime when the melter is emptied. The second canister to be monitored is one filled from the pour turntable, and then transferred to the insulated canister storage compartment (WP-16). This mimics the case where a problem occurs which requires that the canister be temporarily placed in a thermally shielded environment. A third canister, filled on the pour turntable, will also be monitored (WP-17). This data will be included in the WQR and relates to glass durability. The canisters filled from the drain turntable will be subjected to a shorter time of filling which will generate a different temperature profile. This data is required to confirm previous experiments, and to ensure that temperatures are not reached which may cause embrittlement or corrosion of the stainless steel canisters. Since these canisters will be modified to accept thermocouples, they will not be sealed with tapered plugs, decontaminated, or final welded.

\subsection{Canister Welding Performance (DWPF-WP-24)}

The qualification 10 of the DWPF welder, the welding procedure, and the welder operators will be accomplished during these runs. The qualification is 
based upon Section IX of the ASME Code10 as discussed with B. J. Eberhard of EES. For welder qualification, every fifth weld of a total of 100 welds is to be burst tested. In addition, five of the 100 welds are to undergo machining for tensile, fracture, and metallographic examination. Of these five welds, one will come from the first five welds and one from the last five welds. For procedure qualification, 10 consecutive welds will be evaluated. Five of these welds must be burst tested while the other five will be machined for tensile, fracture, and metallographic examination. In total, 32 welds will be examined. The leakrates for all of these welds will be measured. In total, 96 of the required 100 welds will be made using canistered waste forms. The remaining four welds will be made using the threaded nozzles.

The welder operators will be qualified to the welding procedure. Each operator will make one weld.

Confirmation that welds made within the operating window are acceptable will be accomplished from the data obtained to qualify the DWPF welder and welder procedure. As discussed above, all of these sectioned tops will undergo helium leak tests. The welds will then be burst tested or machined to produce specimens for tensile testing, fracture testing, and optical evaluation. One of the welds evaluated will be from the canister which had the ICC plug replaced by a repair plug. In WP-17, final weld plugs containing ceramic rings fabricated from alumina (AlSiMag 614 or equivalent) will be welded into canisters fabricated by coors. Some of these welds will be tested. Both the coors canister and the alumina containing final weld plugs will be from lots which will be used in the intitial radioactive runs.

\subsection{Canister Dimensions before and after Glass Eilling (DWPF-VN-31).}

Previous experiments 11 have indicated that the dimensions of the canisters do not change upon glass filling. Hence, to meet the overall dimensional specifications set forth in the WAPS for the DWPF canistered waste forms, it is sufficienc to procure 
canisters which meet these dimensional specifications. This test is a confirmation that glass filling does not alter the dimensions of the canister. These measurements will be made on eight canistered waste forms: two from the drain turntable, and six from the pour turntable. Canisters from all five vendors will be measured.

\subsection{Visual Inspection of the Canister Surface after Decontamination by Frit Blasting (DWPI-VN-25).}

This test is designed to confirm that frit blasting in the CDC removes the oxide layer from the entire canistered waste form surface. Frit blasting creates a matte finish which is significantly different in appearance from the as-purchased rolled surface. This inspection will take place on six canistered waste forms. Canisters from all five vendors will be tested.

\subsection{SPECIAL NEEDS FOR ACTIVITIFS AND TESTS}

Complete details of the equipment a id special needs for the tests and activities will be found in the individual test plans, corresponding procedures, and task plans. Certain special reeds are noted below.

\subsection{Canister Assignment}

No special needs are required for canister assignment.

\subsection{Canister Sectioning or Wall Removal for Access for Glass Sampling}

Access to the glass for sampling will be achieved by either sectioning or by removal of a portion of the canister wall. In the case of sectioning, a large band saw located in building 673-T at TNX will be used. For removal of the canister wall, an arc-air torch will be required to cut a window at least 12 inches wide over a portion of the length of the canister (see task plan ${ }^{5}$ ). This activity is detailed in a task plan 12 . 
Transportation of the canistered waste forms from the DWPF to TNX (Building 673-T) will be required. Systems to load the canistered waste form onto the truck at DWPF, and to unload it at TNX, will be needed. The overhead crane in building 673-T should be available to lift canistered waste forms off the truck and to move canisters as required within the building. A fork lift truck is also required at TNX. Details of transportation and handling can be found in a task plan 12 .

\subsection{Glass Sampling from the Canistered Waste Form}

Glass samples will be taken according to procedure 4 and distributed for analyses ${ }^{5}$.

\subsection{Canister Archival Facility}

A canister archival facility at $\mathrm{TNX}$ is required. All portions of the sectioned canisters will be archived in this facililty at TNX. Certain canistered waste forms from campaign number one, which have not been cut nor tested, will also be archived at TNX. Details of this facility can be found in a task plan12. Five canistered waste forms from the first campaign will be stored in the GWSB. All 20 of the radioactive canisters from campaign FA-18 will be stored in the GWSB.

\subsection{Free Volume Determination}

Six canisters will be required that contain a thinwalled tap in the canister wall above the projected glass line. EES will design and fabricate the canister taps. A calibrated tank is required for the measurement of free volume. A calibrated scale, capable of weighing up to 5000 pounds, will also be required. Details of the measurement of free volumes are contained in a task plan 13 . 


\subsection{Inner Canister Closure, Repair, and Leak Testing Performance}

A helium leak detection system will be required to test the integrity of the ICC seal after transport to TNX. This will be provided and operated by EES. The DWPF has an independent helium leak detection system to measure the ICC leakrates.

\subsection{Free Liquid, Pressure and Gas Contents Determination.}

A system is required for the measurement of the pressure and relative humidity, organics, free liquid and gas composition inside the canister. The details of this system can be found in the SRTC Task Plan for this test 14. The six modified canisters mentioned in the free volume section will also be required. Relative humidity and temperature measurements within the melt cell, recorded at the time of ICC closure are also required.

It may be necessary to acquire data on a canistered waste form which does not contain a thin-walled tap. This could occur for example, for a canister in which the leak rate of the ICC seal does not meet specification. In this case, facilities must be available such that the canister wall can be predrilled, and an attachment welded on as previously described 6 . This would allow for the same system to be utilized as described above.

\subsection{Canister Temperature Profile Determination.}

This test will require installation of thermocouples in three canisters prior to the test in order to follow the vertical as well as radial temperature profile of the canister and waste glass during pouring and cooling. The capability to receive and record the data from all three canisters within the melt cell is required. 


\subsection{Canister Welding Performance.}

Facilities for the measurement of tensile strength, burst strength, helium leaktightness, microstructure, and fracture strength of the final welds must be available at EES.

\subsection{Canister Dimensions before and after Glass Eilling.}

The canisters designated for these measurements must first be shipped to 740-12A for measurement by $S S Q / Q V$. They must then be shipped back to DWPF where they will be filled with glass. They will then be shipped back to 740-I2A for measurement prior to shipment to TNX. Quality Section must have the necessary equipment for measuring the dimensions of the canisters, before and after glass filling. Details can be found in a task plan 15 .

\subsection{Visual Inspection of the Canister Surface after Derontamination by Frit Blasting}

Rollers which will suppcrt the canistered waste forms in the horizontal position must be in place at TNX. The canistered waste forms will be placed on these rollers and rotated to ensure that the entire surface is visually inspected.

\subsection{DATA COLLECTION}

The DWPF Startup Test Program will produce 126 designated, glass-filled canisters (124 from the pour turntable and 2 from the drain turntable) during six separate campaigns. Data collection will be required for each canistered waste form according to the sequence of tests as outlined in attachments \#1 - 4. The specific data to be collected for each activity and test are listed below.

Some flexibility in data acquisition will be useful in obtaining evidence for compliance with the wAPS. In this section, opportunities for obtaining additional data are also detailed. 


\subsection{Canister Assignment}

No data will be collected here. The unique alphanumeric code for each canister will be used as the identifier to track data acquired from each canistered waste form.

\subsection{Canister Sectioning or Wall Removal for Access for Glass Sampling}

The data collected here will be the distance in inches of the sectioning cuts from the bottom surfaces of the canistered waste forms. For the canistered waste forms which will have a portion of the wall removed, the location of the cut relative to both canister labels must be recorded. The size of the portion of the wall removed must also be recorded. The details of actual dimensions to be recorded will be provided in the procedures for sectioning and wall removal.

\subsection{Glass Sampling from the Canistered Waste Form}

Glass samples collected during this activity will be characterized as detailed in the Glass Sampling Program ${ }^{3}$, Task Plan 5 , and Task Procedure ${ }^{4}$. Glass characterization is not part of this plan. However, data on amount and location of sampling shall be recorded.

\section{4 Canister Archival Facility}

A record detailing exact locations of the various canistered waste forms (including portions of sectioned canisters) within the facility must be made and maintained.

\subsection{Free Volume Determination}

The change in gas pressure and the height of the glass line in the canister will be collected ${ }^{6}$. Six scheduled free volume tests will be performed as presented in attachment \#1. Additional tests may be 
performed if an opportunity occurs, e.g., a problem with the neutron detection system, glass coning or vugging. The weight of each canistered waste form transferred to TNX will be recorded.

\subsection{Inner Canister Closure, Repair, and Leak Testing Performance}

The ICC leakrates of seven of the canistered waste forms will be recorded by DWPF both prior to and after decontamination to ensure that the leaktightness of the temporary seal has not been compromiscd by the decontamination process or subsequent har iling. One of these seven canistered waste forms will have an ICC repair plug while another will have the tapered plug and sleeve pressed down into the canister after retesting the leakrate. Only the canister containing the repair plug will be final welded. The reproducibility of three of the ICC seals will be determined both before and after decontamination.

Once at $\mathrm{TNX}, \mathrm{six}$ of these canistered waste forms (the seventh is the one containing the repair plug which will be final welded) will have their noti? es removed for measurement of leakrates by EES.

\section{5. i Free Iiquid, Pressure and Gas Contents Determination.}

The measurement of the dew points within six canistered waste forms will be carried out. The internal gas pressures will also be measured. The gas composition will be measured using a mass spectrometer. These results will be combined with the ICC leak rates for these six canistered waste forms to demonstrate that water inleakage during decontamination will not occur.

At least one canister (if any are produced) with an ICC which fails the leaktightness criterion will be allowed to proceed through the normal DWPF path without the introduction of the repair plug. The dew point, gas composition, and internal pressure will be measured on this canistered waste form. 


\subsection{Canister Temperature Profile Determination.}

The data to be collected are the vertical and radial temperature profiles within three canistered waste forms as a function of time. The three canisters will be (1) a normally processed canister (2) a canister which will be transferred to the insulated canister storage compartment after filling from the pour turntable, and (3) a canister filled from the drain turntable during the low viscosity run.

\subsection{Canister Welding Performance.}

The final seals of 32 canistered waste forms will be tested for leaktightness. In addition these 32 welds will either be burst tested or machined for tensile, fracture, and optical testing. This data will be used to confirm that good welds are made under normal operations and to qualify both the DWPF welder and welding procedure. During normal operations, the force, time and current parameters for every final closure will be measured and recorded. If welds are found that are close to the edge of the operating window, or made in a non-routine manner, they may also be tested.

\subsection{Canister Dimensions before and after} Glass Filling.

Canister dimensions must be recorded both prior to and after glass filling. These data include but are not limited to canister length, circumference, nozzle dimensions, perpendicularity. Exact details will be forthcoming in a procedure which will be written as part of a task plan 15 .

\subsection{Visual Inspection of the Canister Surface after Decontamination by Frit Blasting}

The canistered waste forms will be placed horizontally on rollers at TNX. The canister can be visually inspected at both ends and over the entire cylindrical 
surface by rotating the canistered waste form for at least one full revolution on the rollers. A description of this inspection must, be recorded.

\subsection{ACCEPTANCE CRITERIA}

The acceptance ciiteria presented here derive mainly from the WAPS specifications.

\subsection{Canister Assignment}

No acceptance criteria for canister assignment.

\subsection{Canister sectioning or hall Removal for Access for Glass Sampling}

No acceptance criteria for sectioning or wall removal.

\subsection{Glass Sampling from the Canistered raste Form}

Glass samples collected during this activity will be characterized as detailed in the Glass Sampling Program. ${ }^{3}$ Glass characterization is not part of this plan.

\subsection{Canister Archival racility}

The canistered waste forms must be maintained in a class C storage facility.

\subsection{Free Volume Determination}

The WAPS state that "The producer shall fill the canister to a height equivalent to at least 808 of the volume of the empty canister". Since the total internal volume is nominally $26 \mathrm{ft}^{3}$ (736.24 liters), the maximum amount of free volume allowed by the specification is $5.2 \mathrm{ft}^{3}$ or 38.9 gallons $(147.25$ liters). The WAPS require that the canistered waste form does not exceed $2,500 \mathrm{~kg}$. The weights will also be used to support the free volume determinations. 


\subsection{Inner Canister Closure, Repair, and Leak Testing Performance}

The inner canister closure seal prior to decontamination must be leaktight such that the leak rate for helium gas does not exceed $2 \times 10^{-4} \mathrm{~atm} \mathrm{cc} / \mathrm{sec}$. The measurement of leaktightness after decontamination at the DWPF must be equivalent to or lower than the first measurement within experimental error for the measurement. The final measurement of this leak rate will be done at EES and will provide a determiration of the accuracy of the DWPF measurement.

\subsection{Free Iiquid, Pressure and Gas Contents Determination.}

The WAPS require that no free liquids and no organics are present in the closed canisters. They also require that the internal gas pressure immediately after closure shali not exceed $150 \mathrm{kPa}(22 \mathrm{psia})$ at $25^{\circ} \mathrm{C}$. The pressure will be measured to ensure that it is less than $7 \mathrm{psig}$. The dew point will be measured to ensure that liquid water is not present (i.e., that the vapor space is not saturated with water). Mass spectrometric data will be obtained for molecular weights less that 200 to ensure that no organic compounds are present within the sensitivity limits of the mass spectrometer for each potential organic contaminant.

\subsection{Canister Temperature Profile Determination.}

There are no acceptance limits here. The temperature profiles will be generated from the temperature data measured at the various locations by the thermocouples.

\subsection{Canister Welding Performance.}

The final weld will be leak tested to ensure that the helium leak rate is less than $1 \times 10^{-7} \mathrm{~atm} \mathrm{cc} / \mathrm{sec}$ for helium which is much more conservative than the $1 \mathrm{x}$ $10^{-4} \mathrm{~atm} \mathrm{cc} / \mathrm{sec}$ helium limit imposed by the WAPS. The burst strength, tensile strength, fracture strength, 
and optical examination of the welds will be performed and the results compared to those obtained from the reference welds made during the parametric welding study.

\subsection{Canister Dimensions before and after Glass Filling.}

The canister dimensions before glass filling must meet. the specifications listed in the canister procurement specifications. The dimensions of the canistered waste form must meet the requirements of the WAPS.

\subsection{Visual Inspection of the Canister} Surface after Decontamination by Frit Blasting

An acceptable decontamination will produce a surface which is uniformly matte over the entire surface, with no apparent oxide film.

\subsection{QDALITY ASSORANCE REQUIREMENTS}

Each participating group will follow their own QA Program. The specific details of the quality assurance requirements as they apply to each of the tests or activities will be included in the individual Test Plans/Task Plans.

\section{0 REFERENCES}

1. DWPF Waste Form Compliance Plan (0), WSRC-IM91-116-0, Revision 1, June, 1992.

2. Office of Environmental Restoration and Waste Management, Waste Acceptance Product Specifications for Vitrified High-Level Waste Forms, USDOE Document EM-343, Revision 0, February, 1993.

3. M. J. Plodinec, Glass Sampling Program During DWPF Integrated Cold Runs (D), WSRC-RP-90-100, Revision 1, March, 1990.

4. M. K. Andrews, Glass Sampling of DWPF

Canisters, GT-OP 3-059, Rev. 0, January, 1993. 
5. M. K. Andrews, R\&D Task Plan. Characterization of Glass Samples from the DWP startup Test Program, WSRC-RP-93-178, Rev. 0, January, 1993.

6. J. R. Harbour and T. J. Miller, Development of the Method for Measurement of the Iree Volume/Fill Beights of Canistered Waste Forms During the DWPE startup Test Program (0), WSRCTR-92-348, Revision 0, 1992.

7. J. R. Harbour, T. J. Miller, and M. J. Whitaker, The Determination of Pressure, Dewpoint, and Composition of the Gas within the Free volume of Canistered Waste Forms (D), WSRC-RP-90-1167, 1990.

8. T. J. Miller, Canister Penetration system, Task Technical Plan, EES 22095, Revision 0, March, 1992 .

9. R. E. Edwards, SGM Run 8 - Canister and Glass Temperatures During Filling and Cooldown, DPST87-801, December, 1987.

10. ASME Boiler and Pressure Vessel Code, Section IX, Qualfication Standard for Welding and Brazing Procedures, Welders, Brazers, and Welding and Brazing Operators, 1992 Edition, July, 1992.

11. S. I. Goudelock, Summary of Post-rilling Operations for DWPE Reference Drop Test Canisters, WSRC-RP-89-510, Revision 0, June, 1989.

12. J. R. Harbour, Task Plan: Canistered Waste Form Sampling, Testing, and Archiving During the DWPE Startup Test Program (J), WSRC-RP-92-1233, Rev. 0, December, 1992.

13. J. R. Harbour, R/D Task Plan: Meaurement of Canister Free Volume and Glass Fill Height for Canisters Filled During the DWP startup Test Program, WSRC-RP-92-1386, Rev. 0, February, 1993.

14. J. R. Harbour, R/D Task Plan: Measurement of the Composition, Pressure, And Dew Point of the 
Free Volume Gas Within Canistered Waste Forms Produced During the DHPF startup Test Program, WSRC-RP-92-1387, Rev. 0, February, 1993.

15. J. R. Harbour, R/D Task Plan: Measurement of Canister Dimensions Prior to and After Glass rilling on Canistered waste Forms Produced During the DWP startup Test Program, WSRC-RP-921385, Rev. 0, February, 1993.

9.0 ATTACEMENTS

\#1. Testing sorted by planned sequence number.

\#2. Testing sorted by canister number.

\#3. Testing summary.

\#4. Test canisters - sequence of testing. 


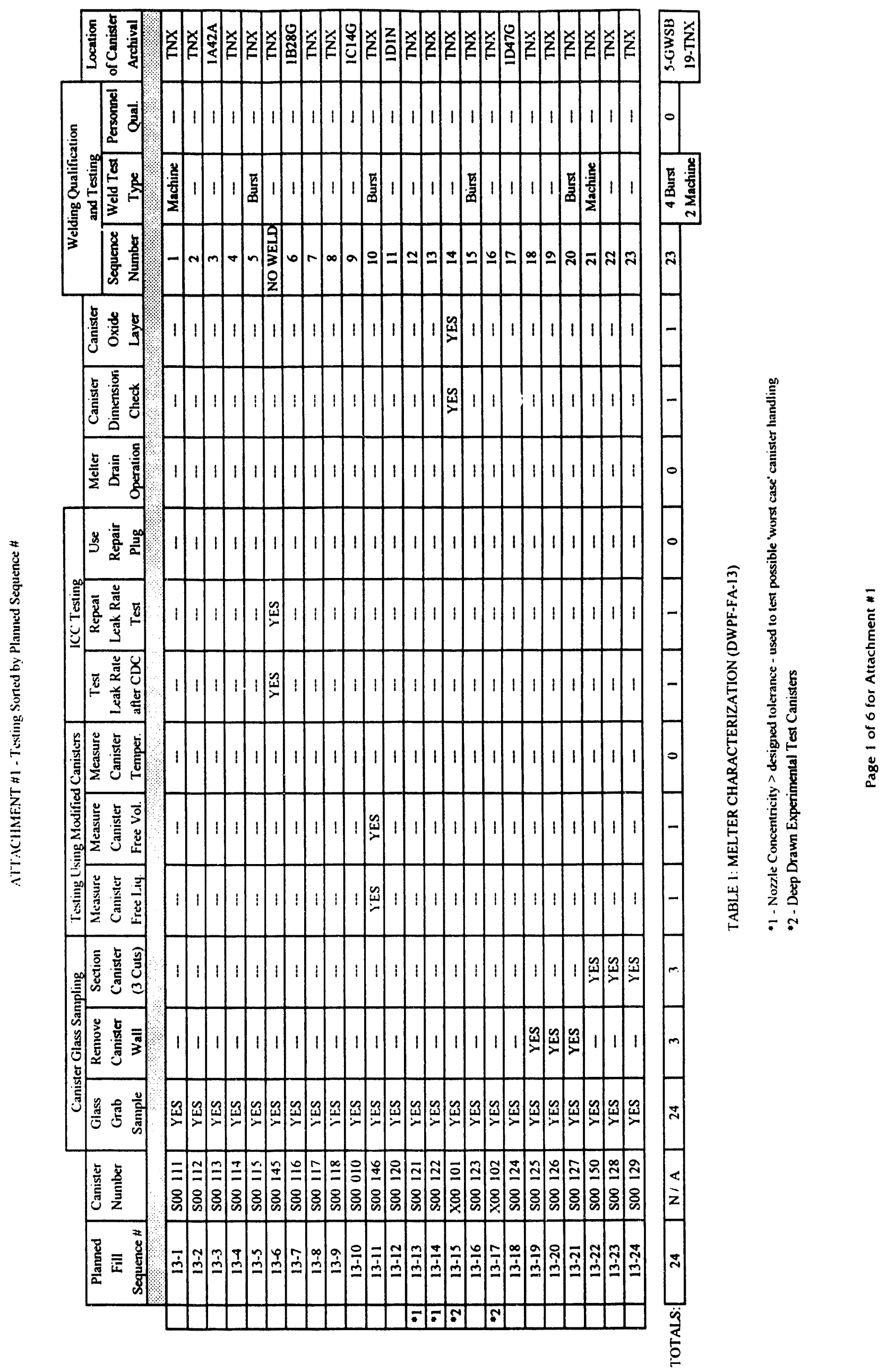




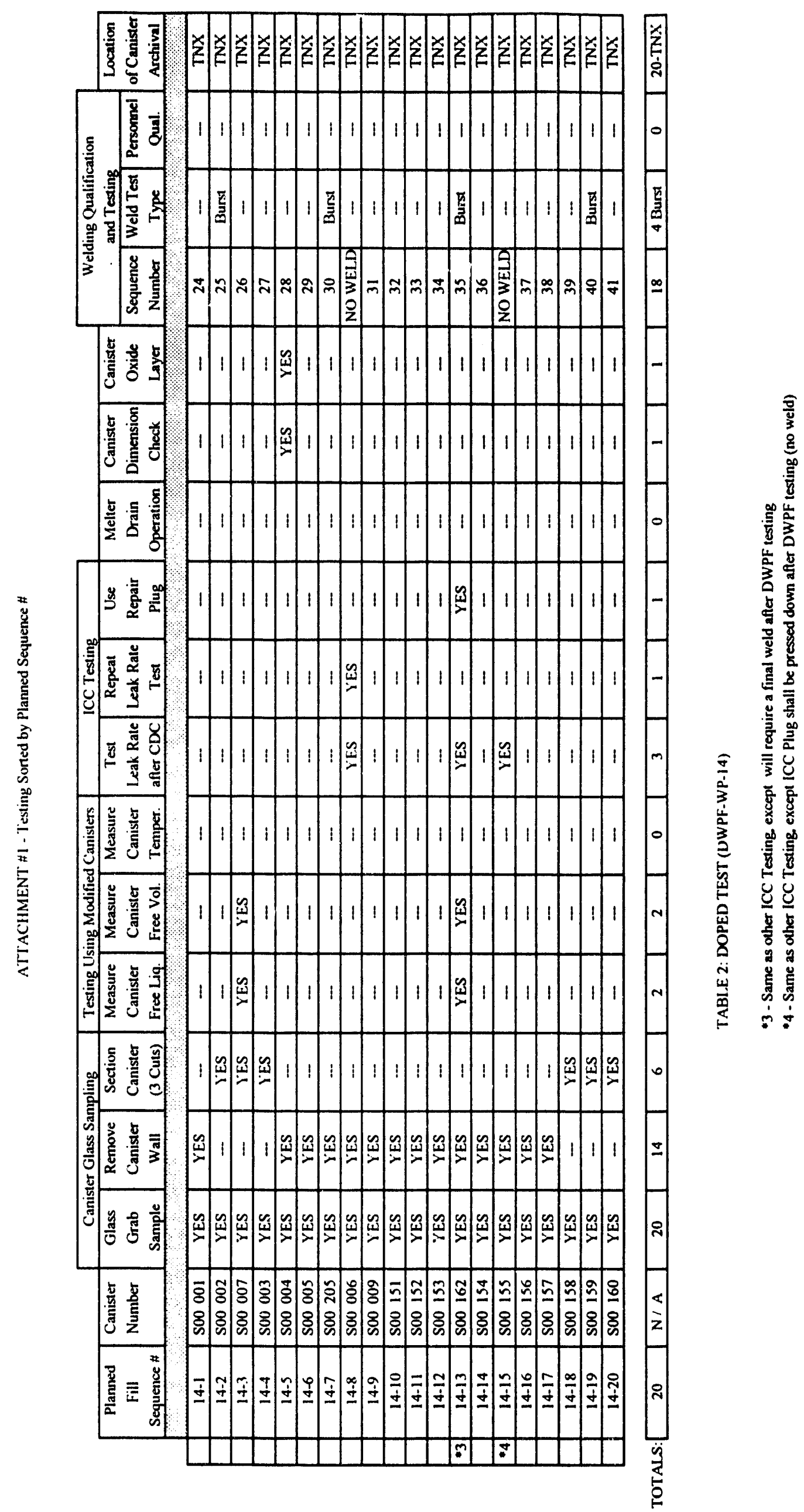




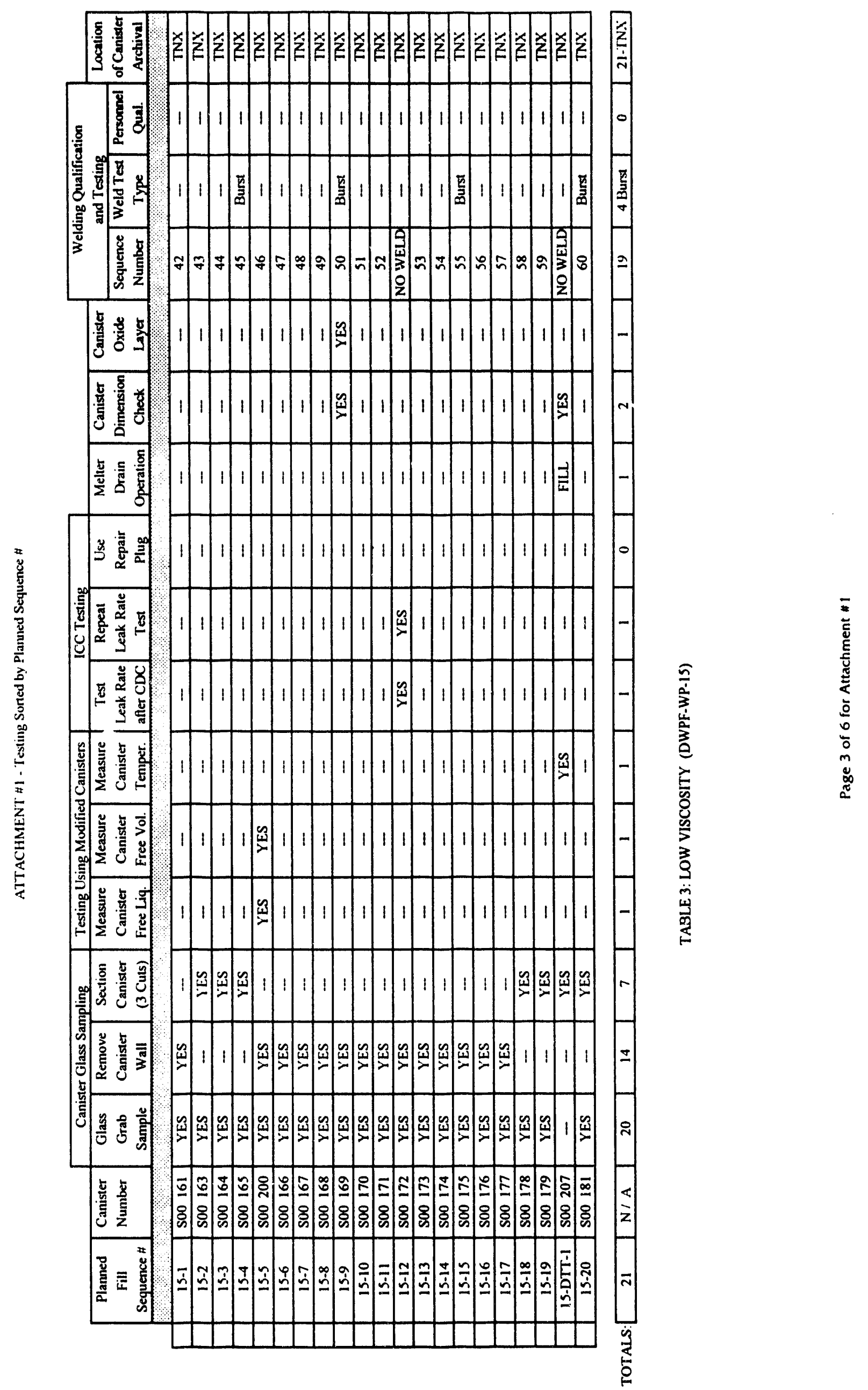




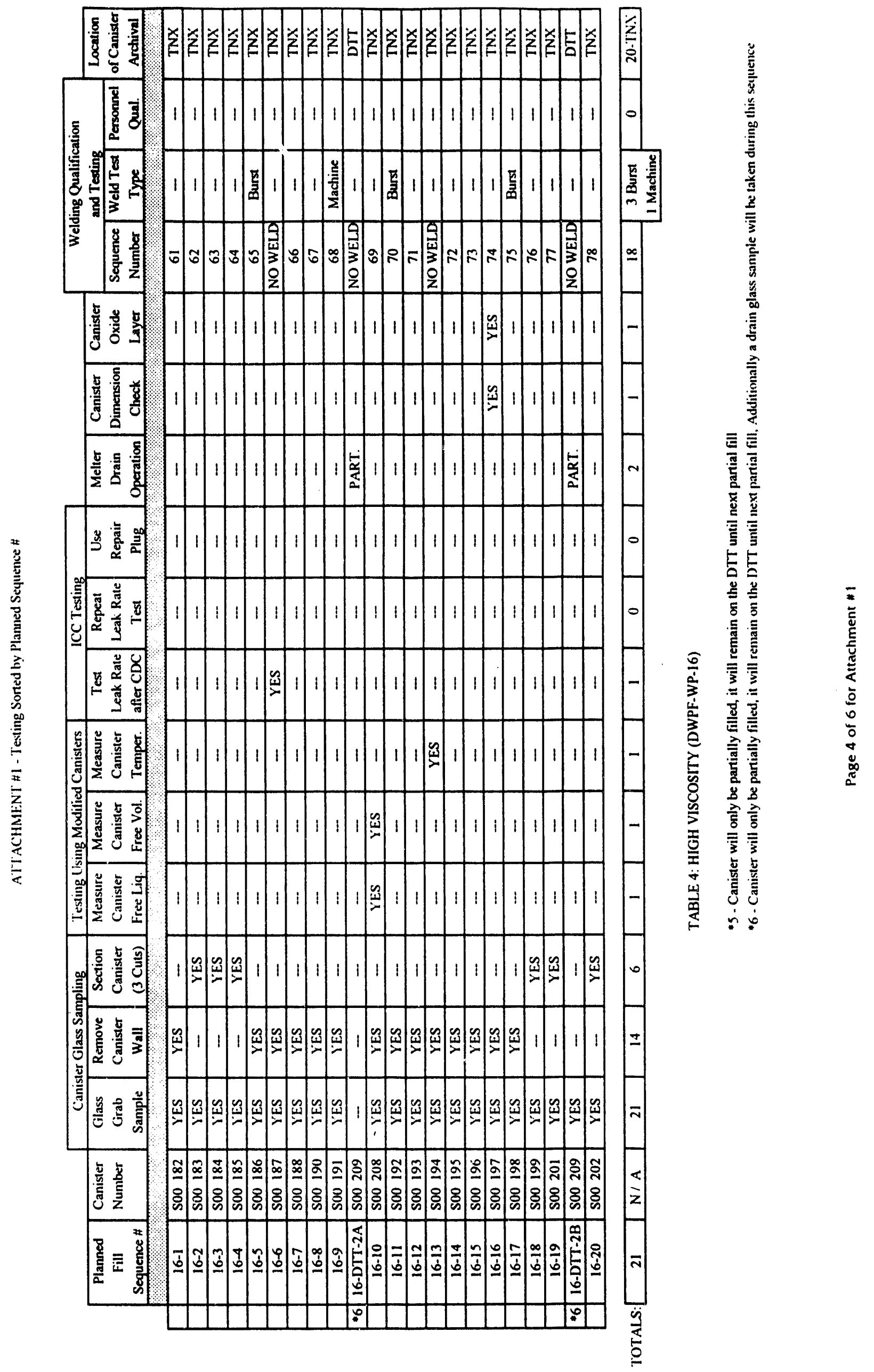




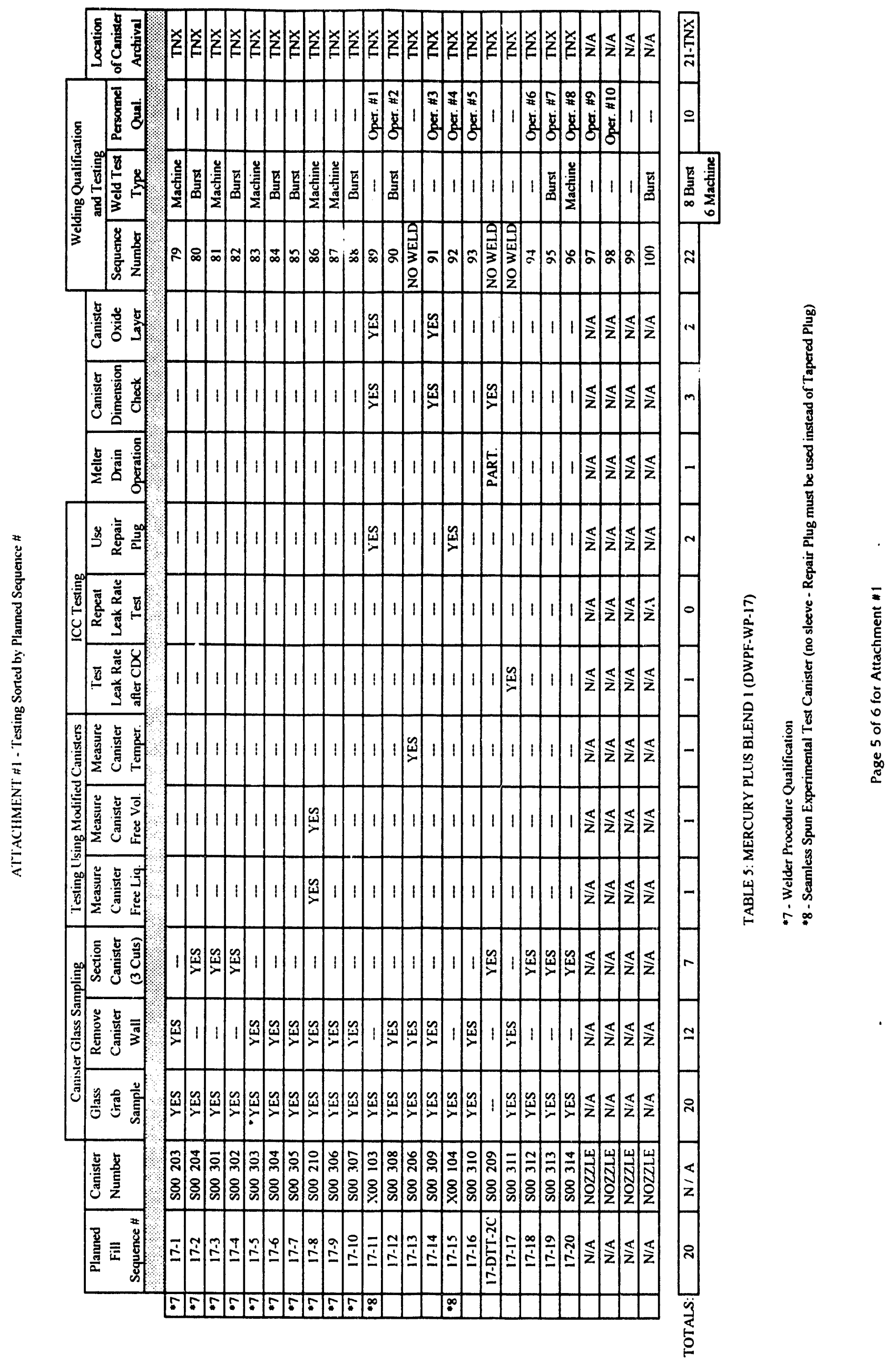




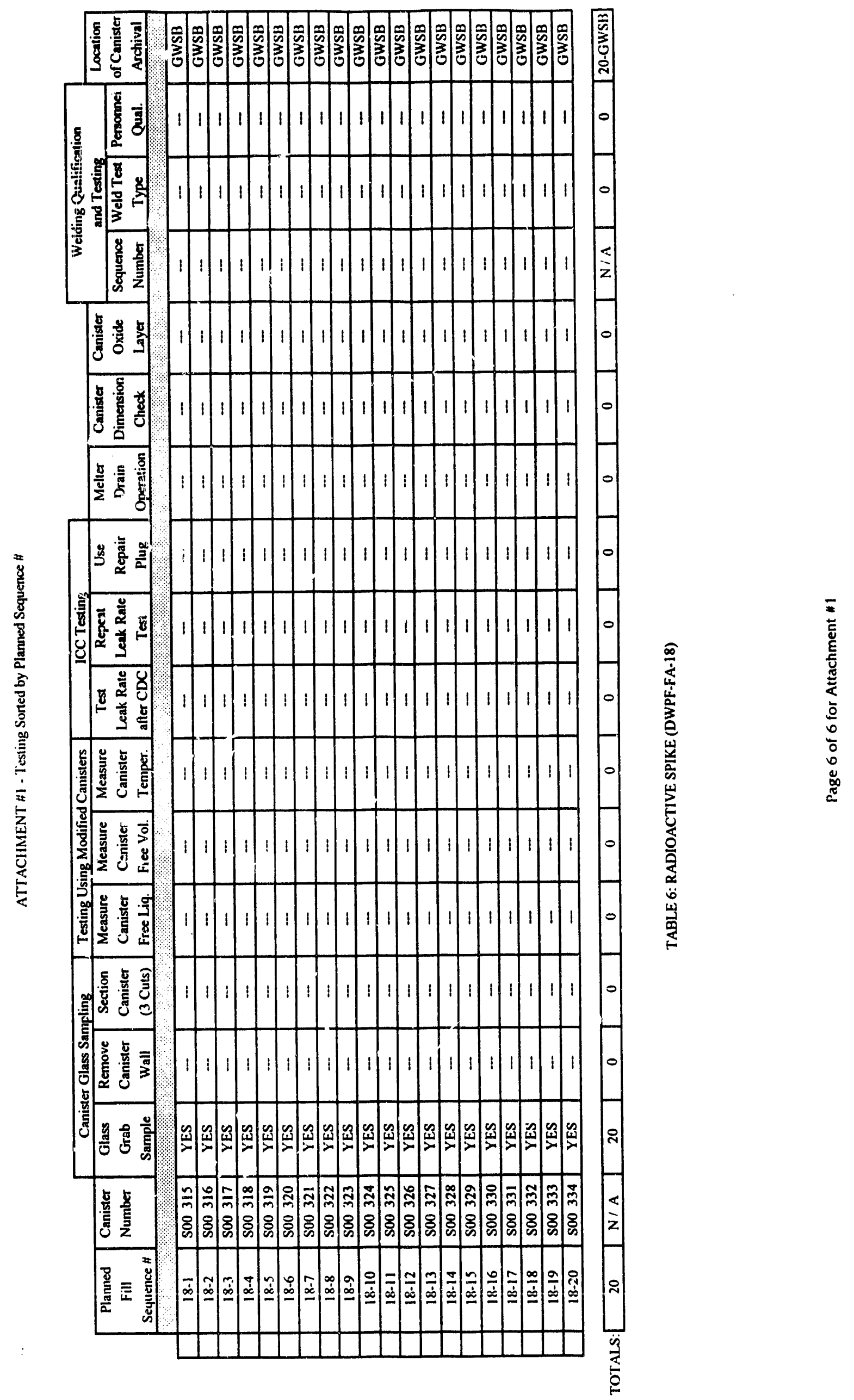




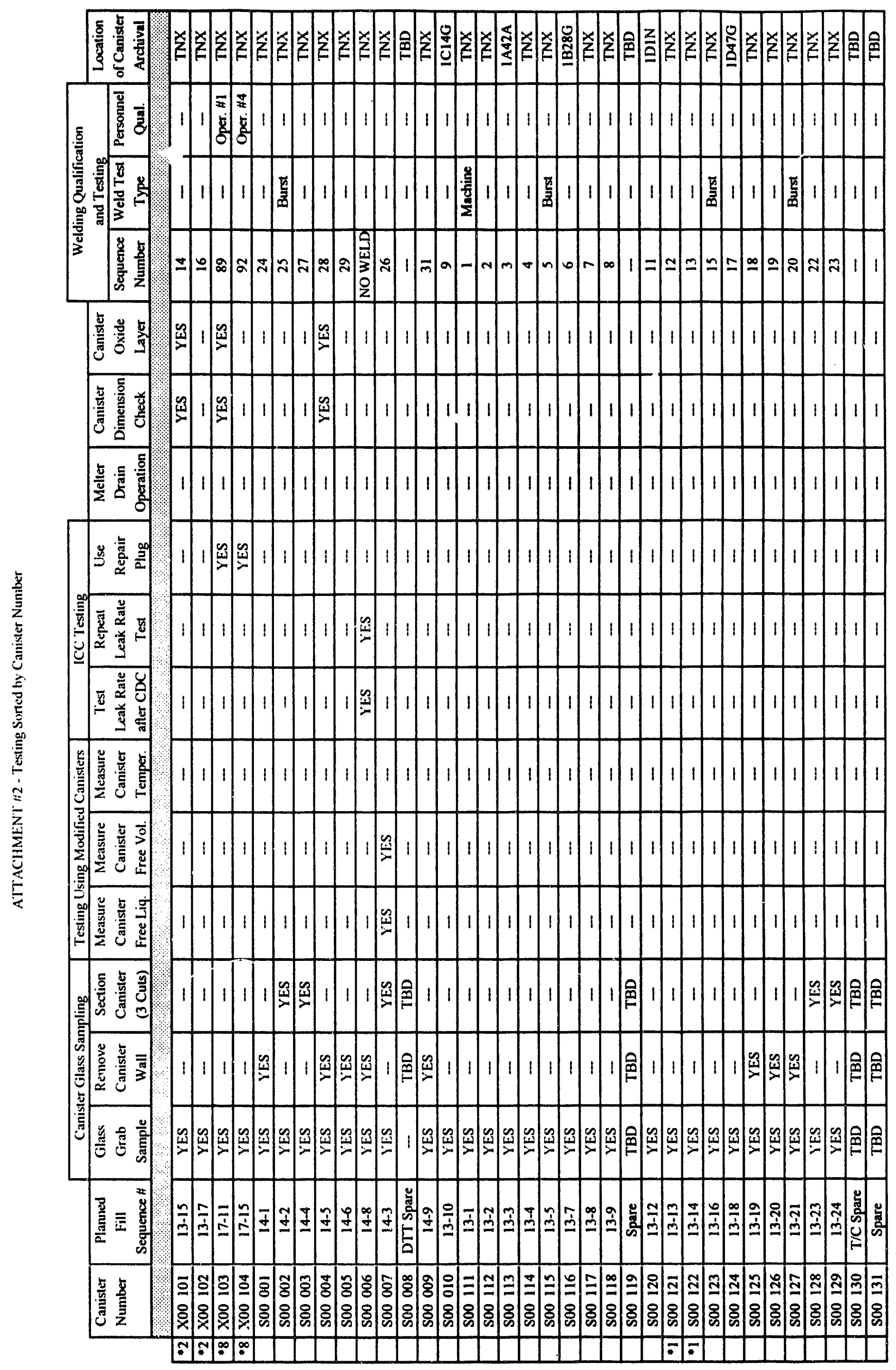




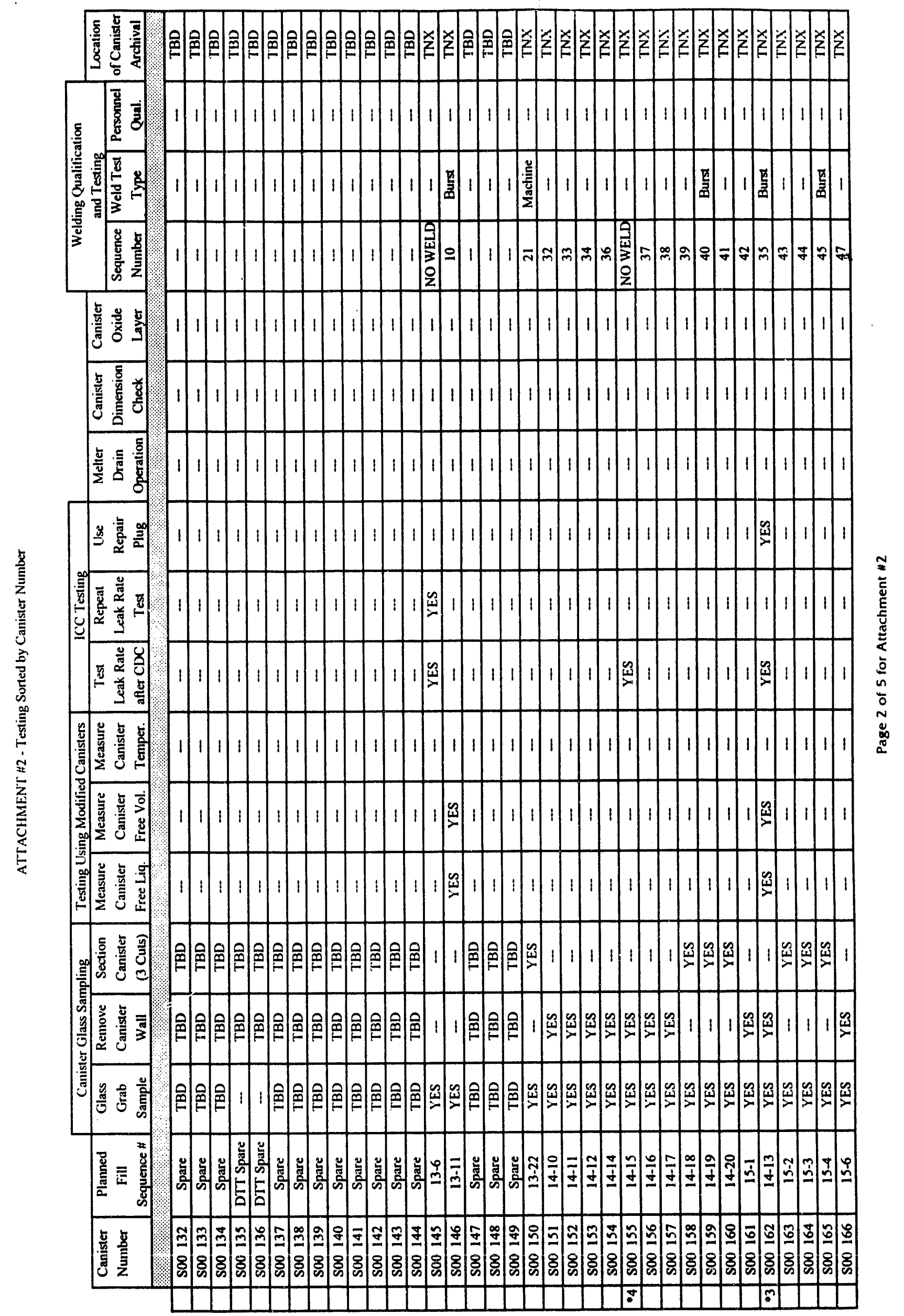




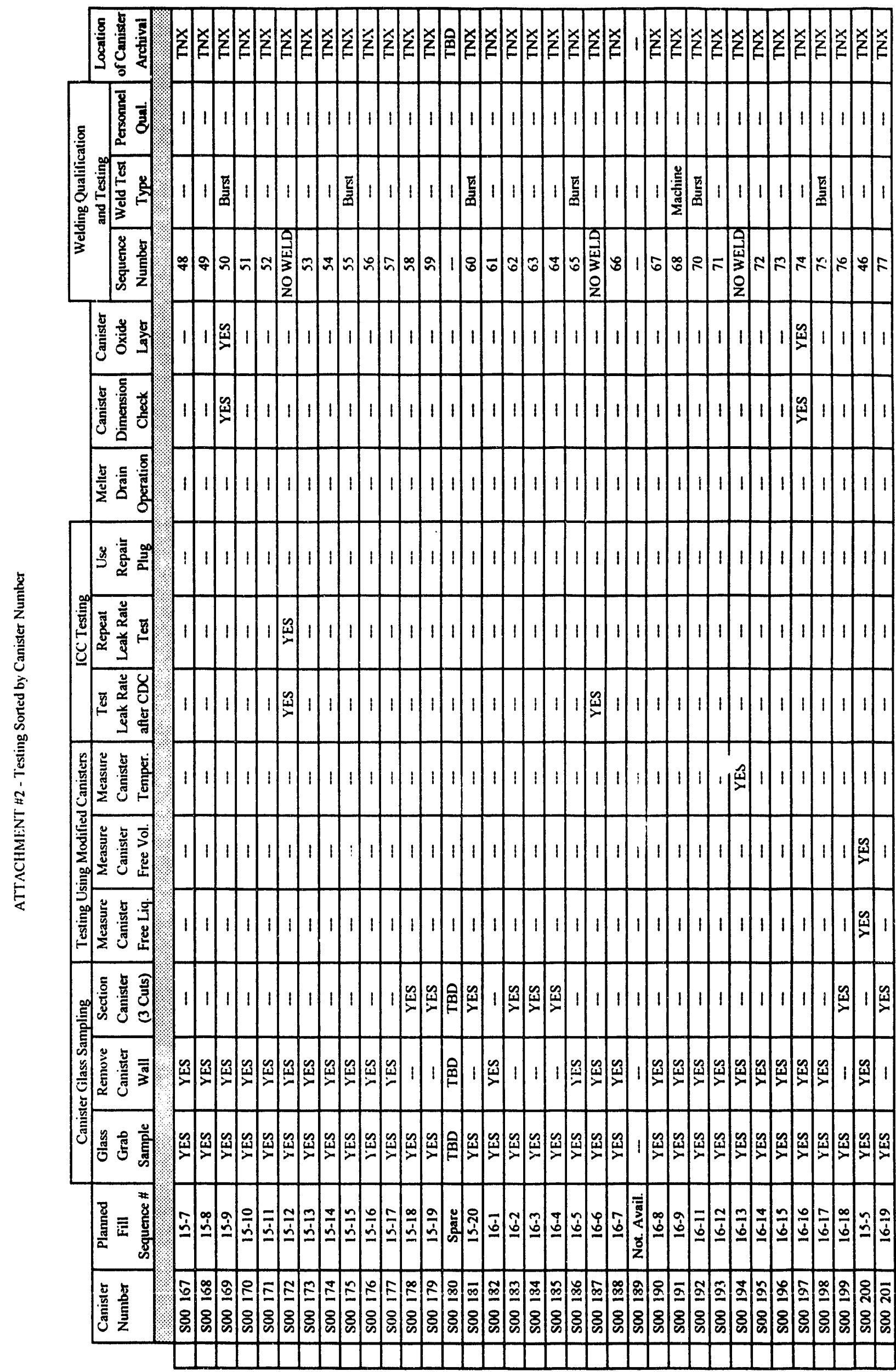




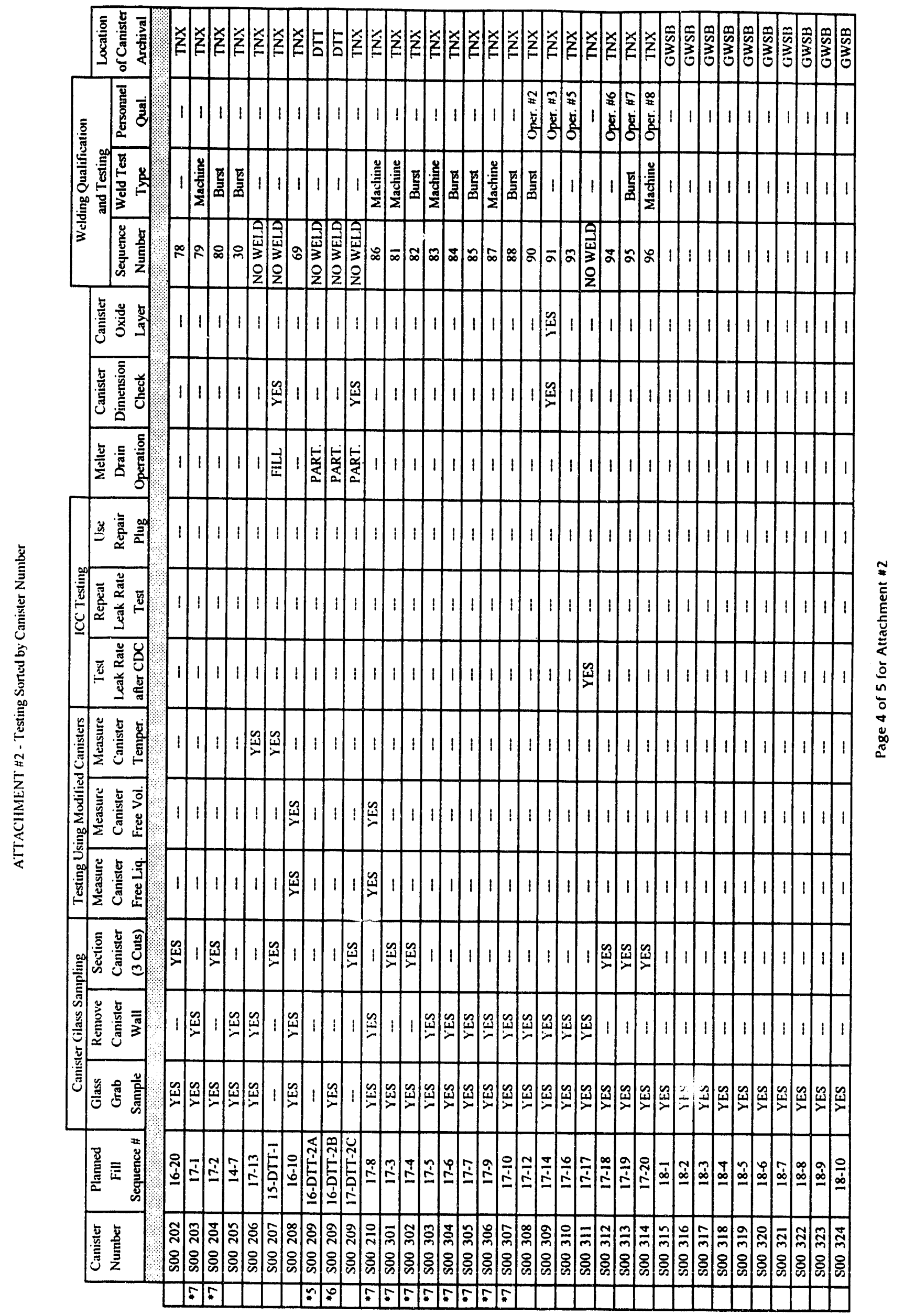



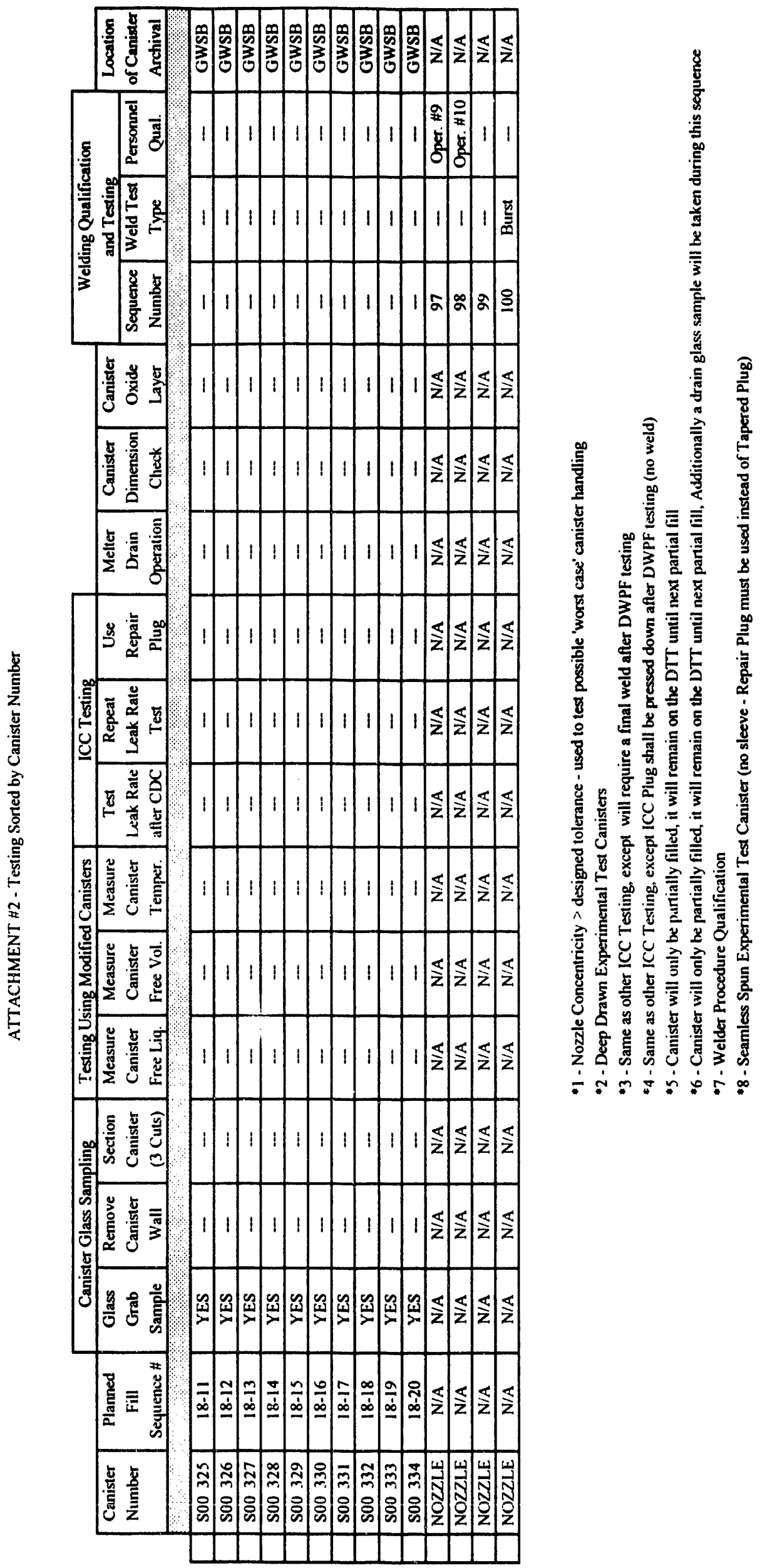

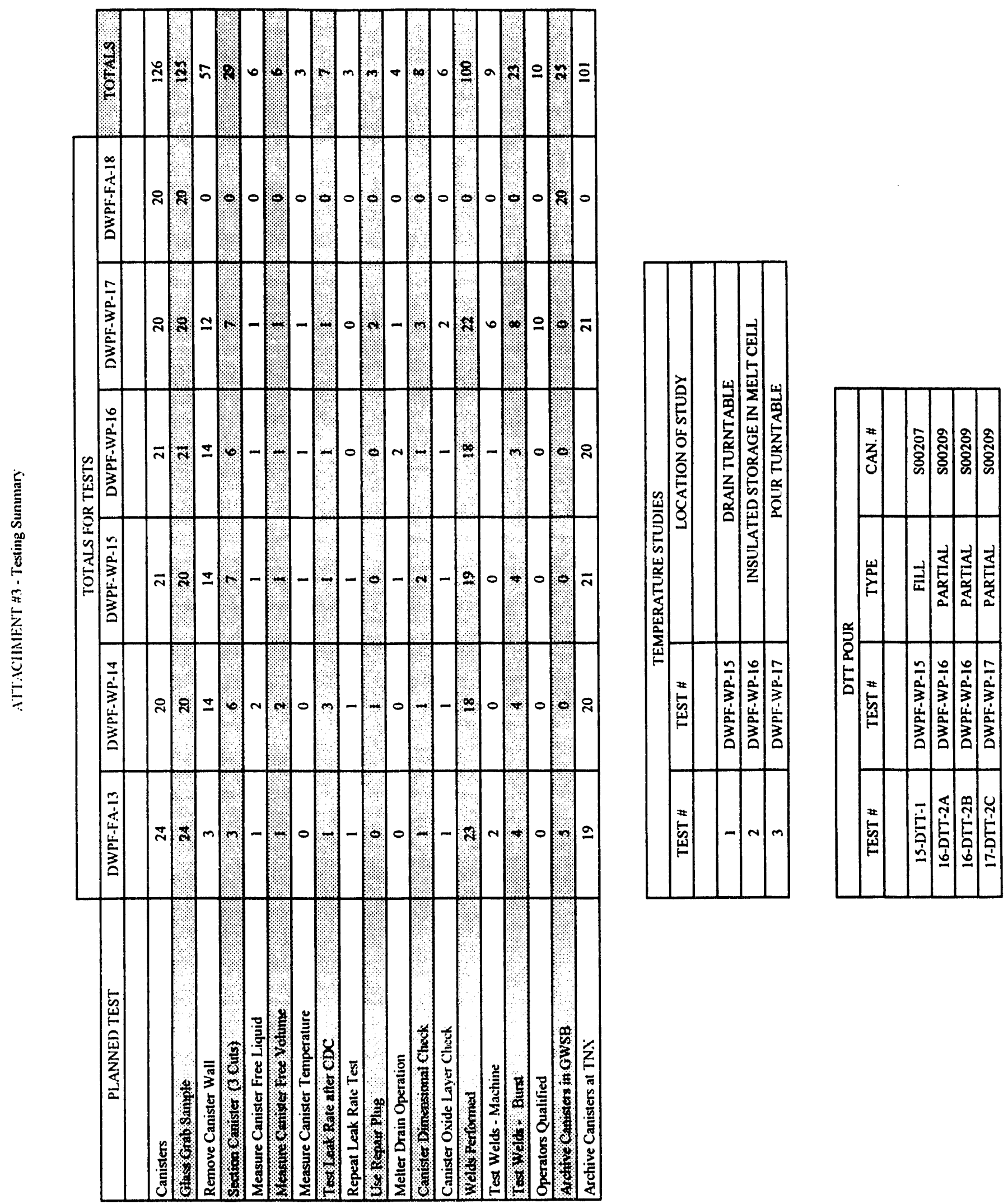
Attachment \#4: Test Canisters - Sequence of Testing Page 1 of 7
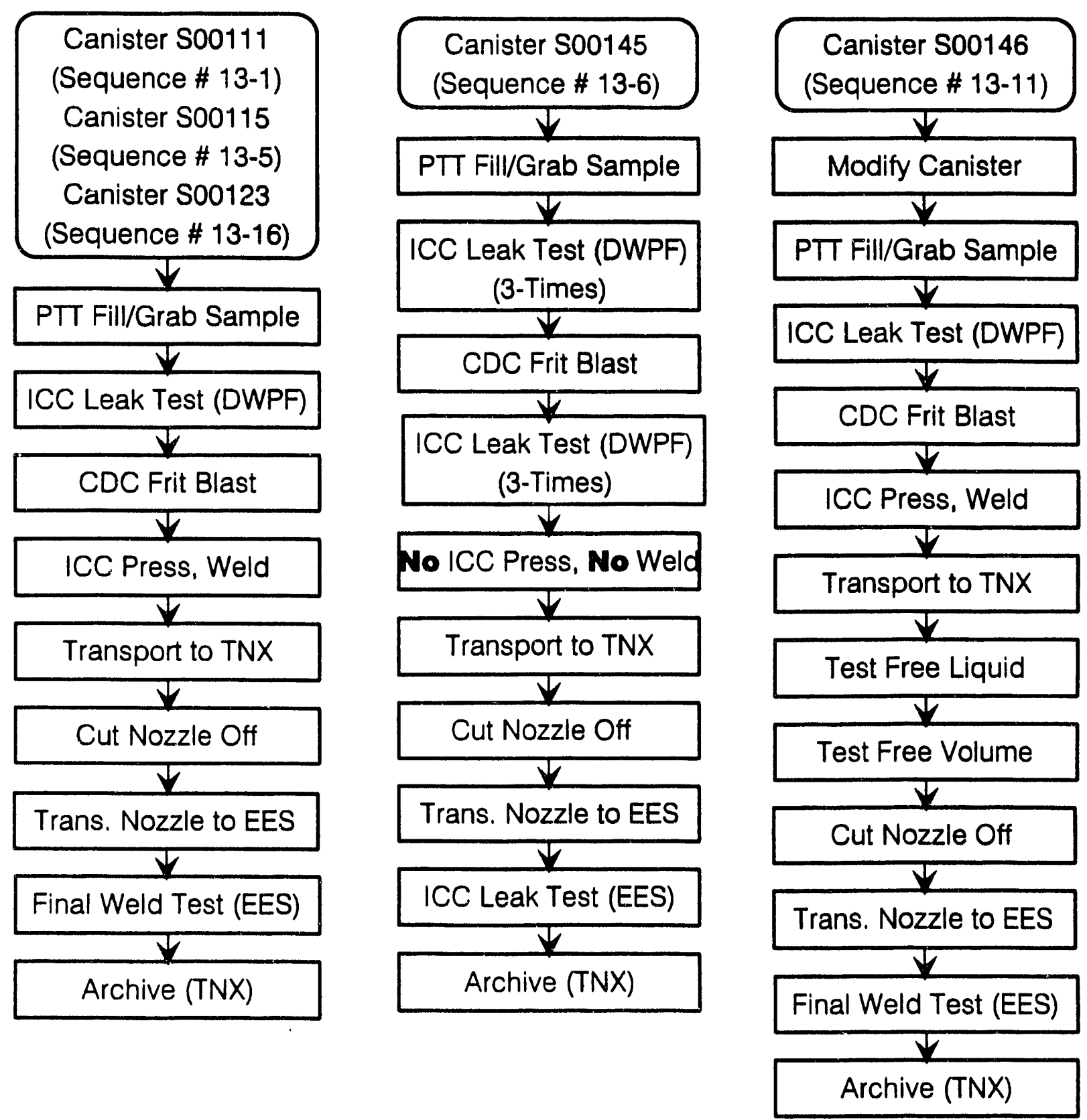
Attachment \#4: Test Canisters - Sequence of Testing

Page 2 of 7

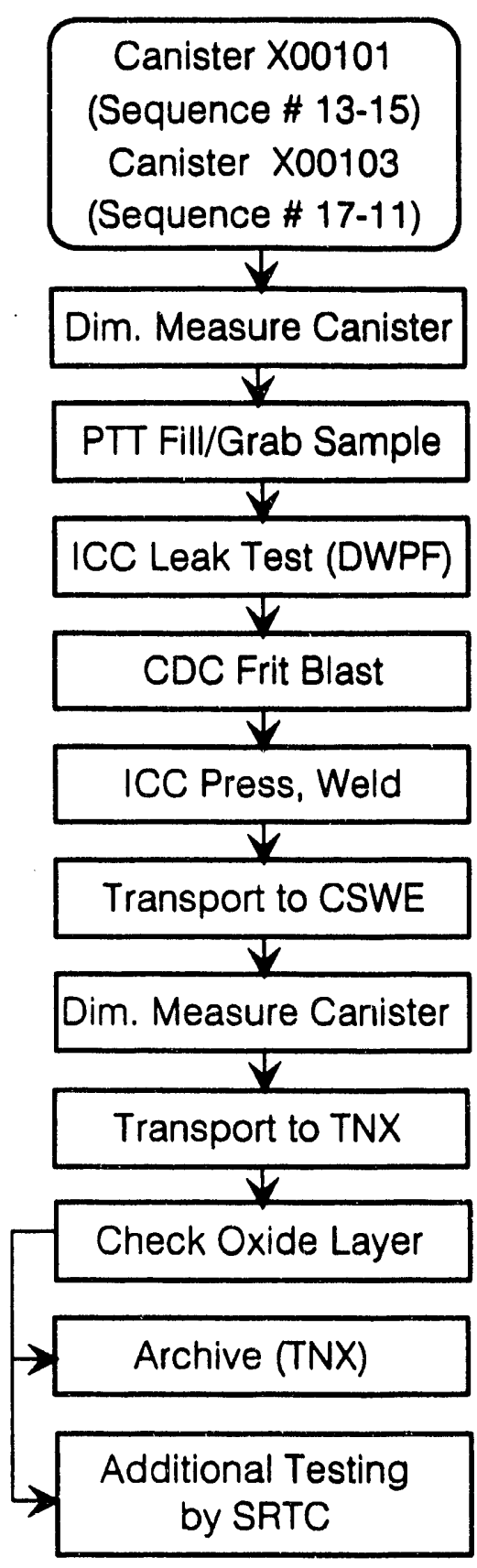

Canister S00127

(Sequence \# 13-21)

Canister 500205

(Sequence \# 14-7)

Canister S00175

(Sequence \# 15-15)

Canister S00186

(Sequence \# 16-5)

Canister S00191

(Sequence \# 16-9)

Canister S00192

(Sequence \# 16-11)

Canister $\mathbf{S 0 0 1 9 8}$

(Sequence \# 16-17)

Canister $\mathrm{S00203}$

(Sequence \# 17-1)

Canister $\mathrm{S00303}$

(Sequence \# 17-5)

Canister 500304

(Sequence \# 17-6)

Canister $\mathbf{5 0 0 3 0 5}$

(Sequence \# 17-7)

Canister S00306

(Sequence \# 17-9)

Canister $\mathrm{S00307}$

(Sequence \# 17-10)

Canister 500308

(Sequence \# 17-12)

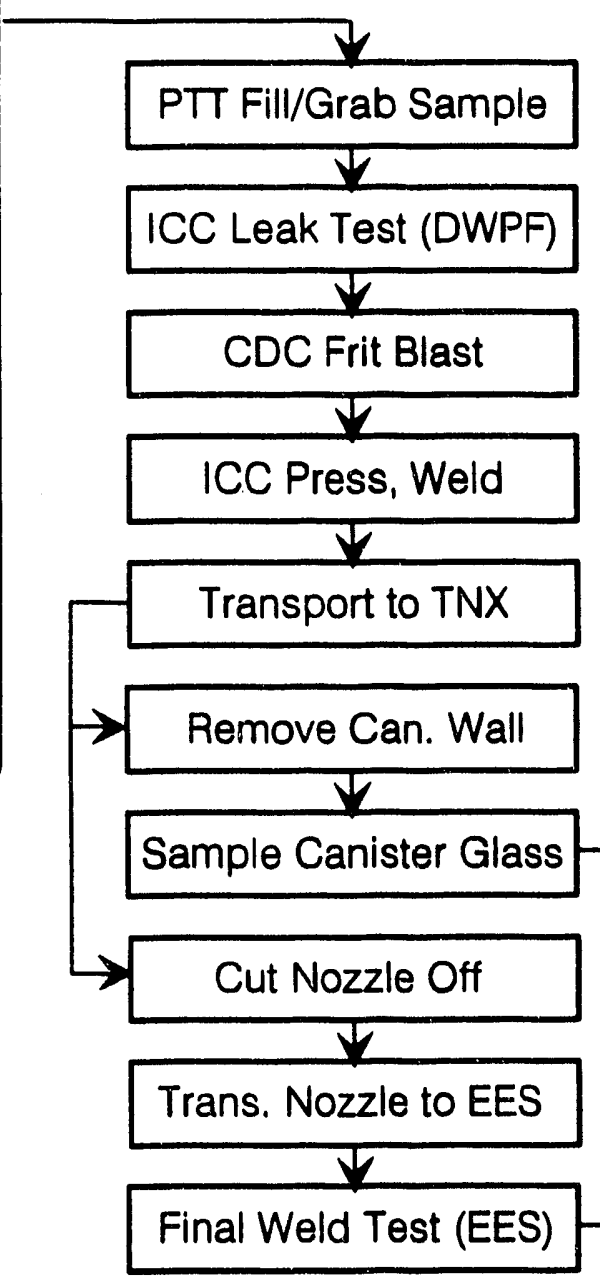

Archive (TNX) 


\section{Attachment \#4: Test Canisters - Sequence of Testing}

Page 3 of 7

Canister S00150

(Sequence \# 13-22)

Canister S00002

(Sequence \# 14-2)

Canister S00159

(Sequence \# 14-19)

Canister S00165

(Sequence \# 15-4)

Canister S00181

(Sequence \# 15-20)

Canister $\mathbf{S 0 0 2 0 4}$

(Sequence \# 17-2)

Canister S00301

(Sequence \# 17-3)

Canister 500302

(Sequence \# 17-4)

Canister $\mathrm{S} 00313$

(Sequence \# 17-19)

Canister S00314

(Sequence \# 17-20)

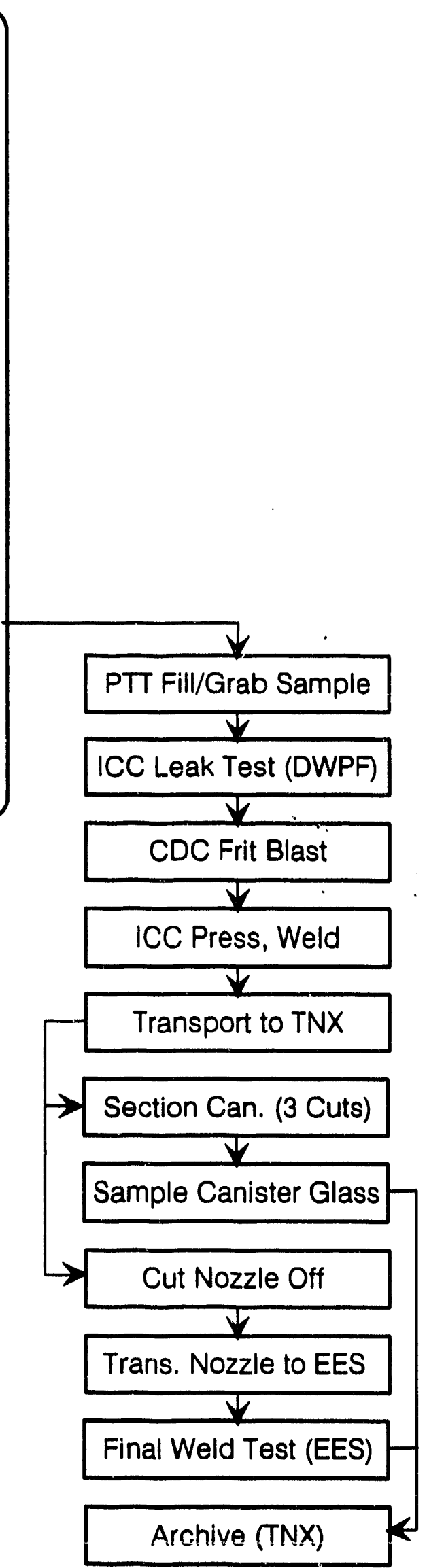

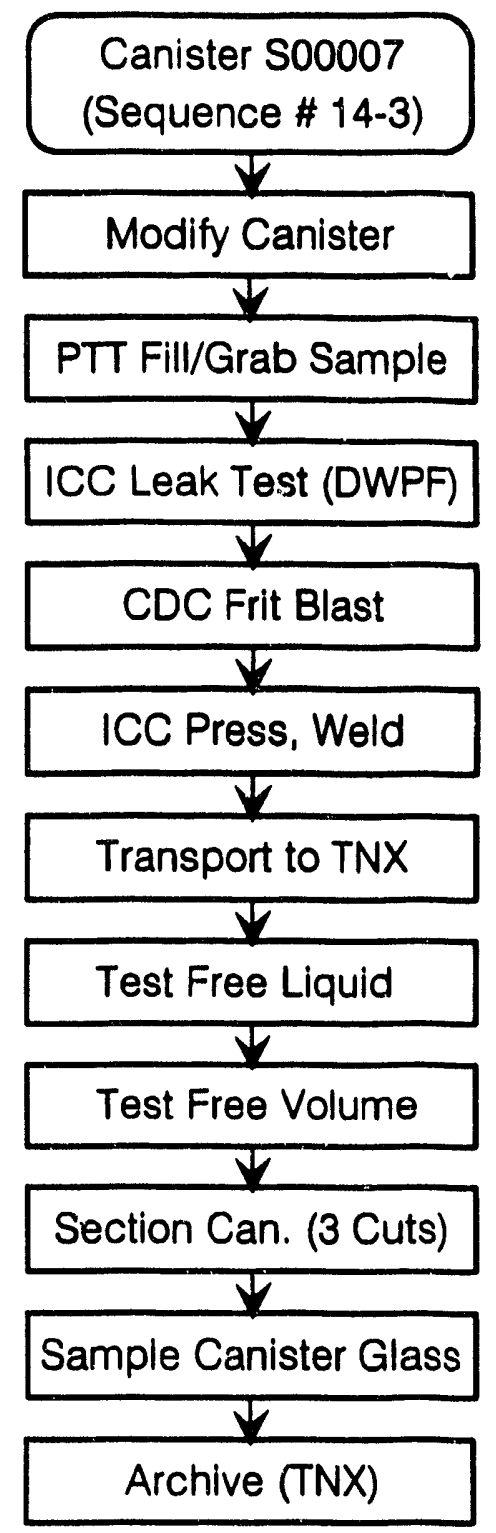




\section{Attachment \#4: Test Canisters - Sequence of Testing}

Page 4 of 7
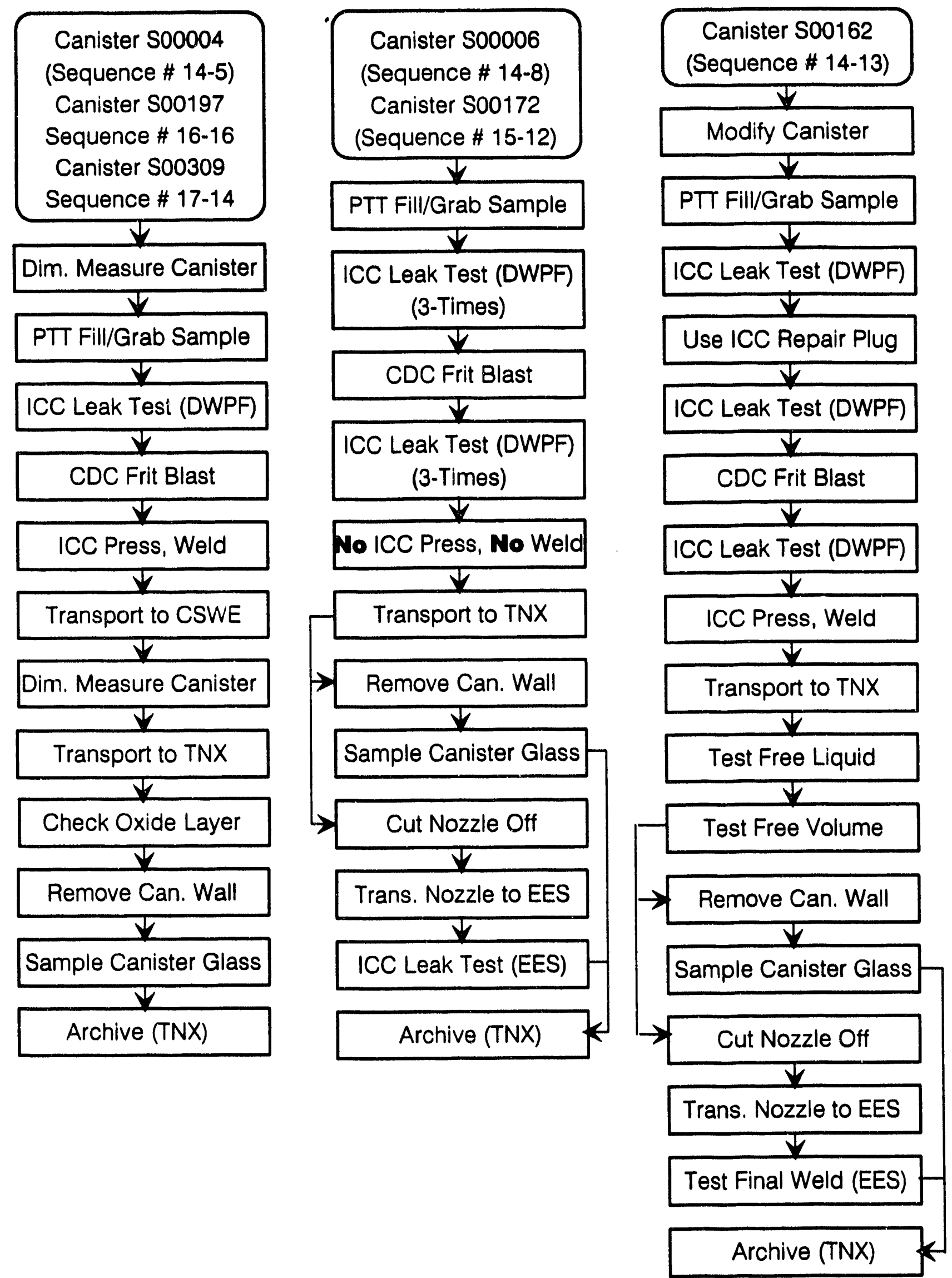
Attachment \#4: Test Canisters - Sequence of Testing

Page 5 of 7

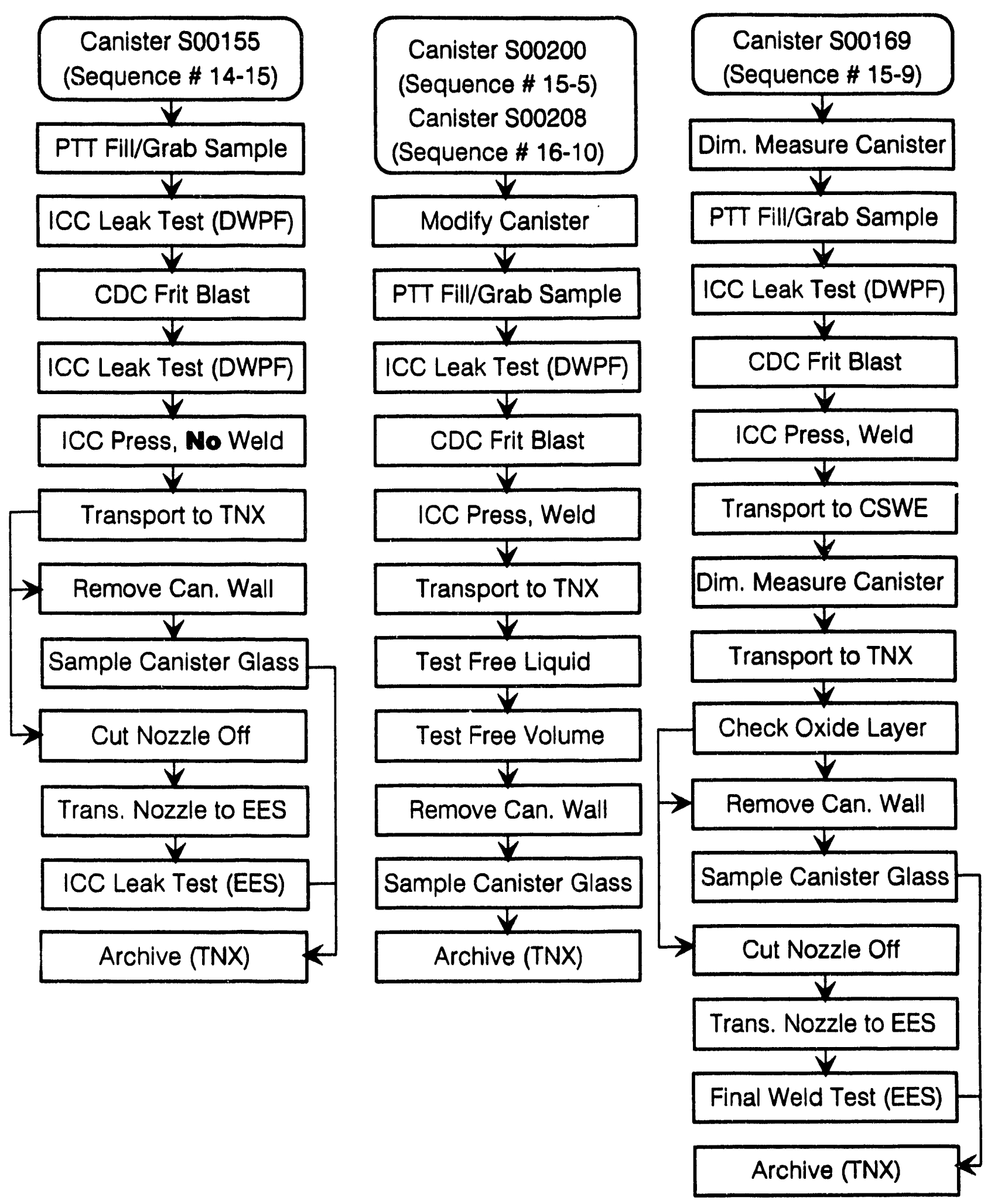


Attachment \#4: Test Canisters - Sequence of Testing

Page 6 of 7
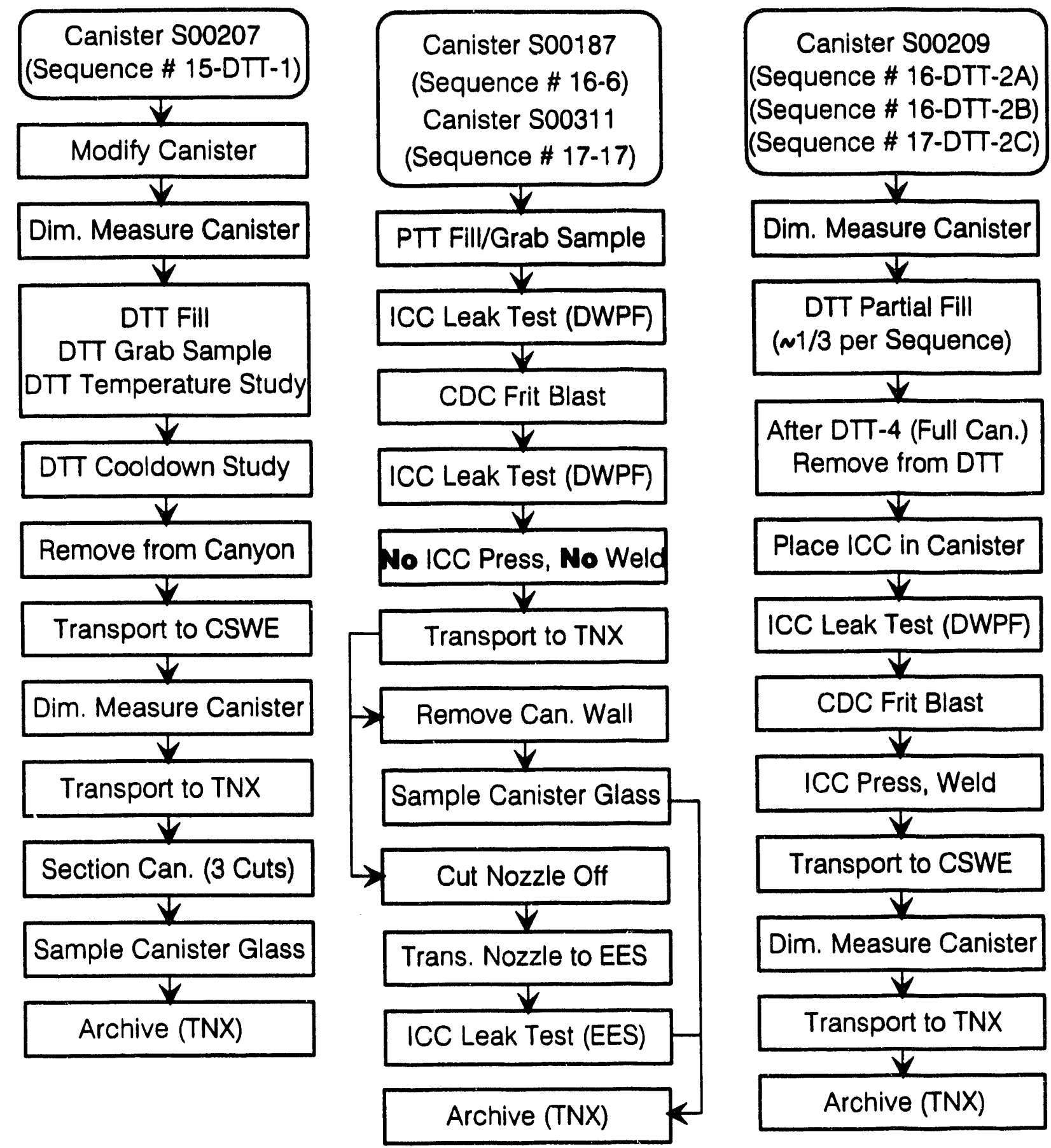
Attachment \#4: Test Canisters - Sequence of Testing

Page 7 of 7
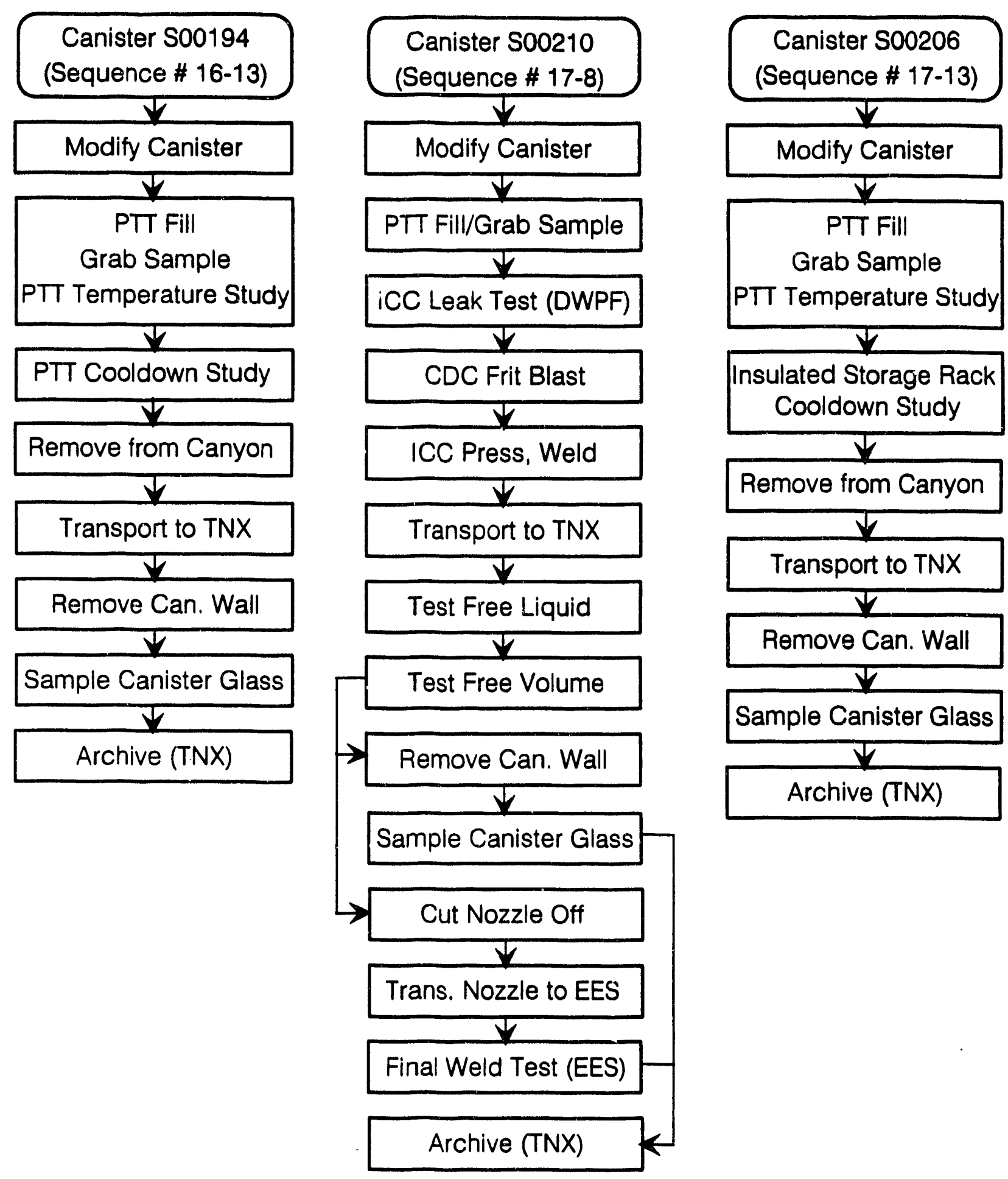


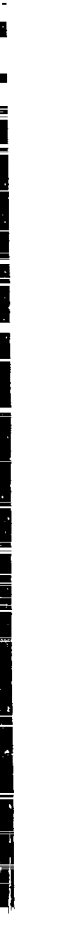

